\title{
Transatlantica
}

Revue d'études américaines. American Studies Journal

\section{Imagining Jefferson and Hemings in Paris}

\section{Suzanne W. Jones}

\section{(2) OpenEdition}

Journals

Édition électronique

URL : http://journals.openedition.org/transatlantica/5391

DOI : 10.4000/transatlantica.5391

ISSN : 1765-2766

Éditeur

AFEA

Référence électronique

Suzanne W. Jones, «Imagining Jefferson and Hemings in Paris », Transatlantica [En ligne], 1| 2011, mis en ligne le 07 janvier 2012, consulté le 29 avril 2021. URL : http://journals.openedition.org/ transatlantica/5391; DOI : https://doi.org/10.4000/transatlantica.5391

Ce document a été généré automatiquement le 29 avril 2021.

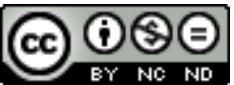

Transatlantica - Revue d'études américaines est mis à disposition selon les termes de la licence Creative Commons Attribution - Pas d'Utilisation Commerciale - Pas de Modification 4.0 International. 


\title{
Imagining Jefferson and Hemings in Paris
}

\author{
Suzanne W. Jones
}

1 In Yearning: Race, Gender, and Cultural Politics, cultural critic bell hooks argues that "no one seems to know how to tell the story" of white men romantically involved with slave women because long ago another story supplanted it: "that story, invented by white men, is about the overwhelming desperate longing black men have to sexually violate the bodies of white women." Narratives of white exploitation and black solidarity have made it difficult to imagine consensual sex and impossible to imagine love of any kind across the color line in the plantation South. hooks predicted that the suppressed story, if told, would explain how sexuality could serve as "a force subverting and disrupting power relations, unsettling the oppressor/oppressed paradigm" (57-58). By rethinking and reimagining the relationship between Thomas Jefferson and Sally Hemings, contemporary novelists, filmmakers, and historians have exposed this "suppressed story," the bare bones of which were first made public in 1802 by journalist James Callendar during Jefferson's first term as U.S. President and then covered up by professional historians for almost 175 years.

2 As novelist Ralph Ellison pointed out, historical fiction must sometimes serve as the repository for historical truth when the collective historical memory has repressed the facts. In 1979 Barbara Chase-Riboud's best-selling novel Sally Hemings allowed readers to enter the mind and heart of the shadowy figure that historian Fawn Brodie had brought back into the public consciousness in 1974, and in so doing enabled readers to believe that Jefferson might have had a long-term relationship with her. ChaseRiboud's fictional portrait clearly upset Jefferson's defenders, but the word that CBS might make the novel into a miniseries unnerved them, causing historians Virginius Dabney and Dumas Malone to intervene. Although they claimed that they were worried about historical accuracy, historian Annette Gordon-Reed believes that they were even more worried by the nature of the medium itself: "If a beautiful woman appears on screen as a capable and trustworthy person, [...] all talk about impossibility [of a liaison] would be rendered meaningless" (Jefferson and Hemings, 182-83). Over fifteen 
years later, the film and the miniseries that eventually were produced have proved Gordon-Reed right. Today visitors to Jefferson's Monticello routinely view, seemingly without surprise or dismay, a twenty-minute documentary that briefly mentions the liaison.

In examining four representations that have shaped the public acceptance and understanding of Jefferson and Hemings' relationship, I am limiting my analysis to the crucial twenty-six-month period in Paris (1787-89), when Jefferson first came to know Hemings as a young woman, rather than the girl he remembered from Monticello. Barbara Chase-Riboud's novel Sally Hemings, the Merchant-Ivory-Jhabvala film Jefferson in Paris (1995), the Haid-Andrews TV movie Sally Hemings: An American Scandal (2000), and Annette Gordon-Reed's prize-winning family history The Hemingses of Monticello (2008), all postulate answers to the questions most often asked about the beginning of the Jefferson-Hemings liaison: What attracted Thomas Jefferson to Sally Hemings? What attracted Hemings to Jefferson? Why would Jefferson give up the cosmopolitan artist Maria Cosway for a relationship with a slave? Why would Hemings leave France, where she was a free woman, to return to slavery in Virginia? Could a slave owner love a slave? Could a slave love her enslaver? That these final questions are always generalized in this way-with, as Gordon-Reed points out, the erasure of individual identities-illustrates the difficulty of representing such a relationship, or getting beyond what bell hooks terms the "oppressed/oppressor paradigm." Some might ask, why try? What's the point, especially if the result were to obscure the effects of the power dynamic? Jefferson was the enslaver, Hemings the enslaved; he was white, she was black; he had absolute control over her, she none over him.

Such a reduction of the two people to symbols inherent in the power relationship induced by slavery and to prevailing ideas about racial identification does little to penetrate the historical mystery of their intimate relationship. As historian Winthrop Jordon concludes, "we are left to guess, without explicit evidence, that Thomas Jefferson found Sally Hemings at least enough one of his own to permit a sexual relationship. Her appearance, dress, demeanor, and diction may well have been sufficiently close to his world to permit him to engage with her intimately with whatever complicated combination of such emotions as affection and dominance we will never know" ("Redux", 50). While Sally Hemings would not have thought of herself as white, she may not have thought of herself simply as black or contemplated "the uses of black solidarity" among people of African ancestry no matter their skin tone, (Gordon-Reed, Hemingses, 335). Similarly although Jefferson may have written in Notes on the State of Virginia that dark-skinned people were unattractive and intellectually inferior (137-141), he surrounded himself with racially mixed people at Monticello. Winthrop Jordan points out that Jefferson treated all members of the extended Hemings family "as standing in a different category than all his other slaves" ("Redux", 48), perhaps because they were blood kin to his wife Martha. He gave them certain freedoms within their slave status, allowing them to earn their own money, housing them away from the slaves who labored in his fields down the mountain, and training them to be skilled artisans: for example, Sally's uncle John became a master carpenter and her brother James a French chef. Jefferson's Monticello was in some respects a world apart, a place where Gordon-Reed argues that Jefferson shaped the Hemings family members to his needs (Hemingses, 115). 
The relationship between Thomas Jefferson and Sally Hemings may never have begun had she not come to Paris. Although Jefferson requested that an older female slave escort his daughter to Paris, fourteen-year old Sally accompanied Mary (known as Polly), and because of Polly's bond with Sally, Jefferson decided she should remain. A century later, Henry Adams argued that Jefferson was able "to breathe with perfect satisfaction nowhere except in the liberal, literary, and scientific air of Paris in 1789" (101). American artists and scholars have long viewed the French as a people who value the aesthete and the intellectual; Americans marginalized or discriminated against in the U.S. have long perceived Paris as a place where they can live and love as they please. If Paris matched Jefferson's cosmopolitan tastes, it also brought the widowed Virginian into close personal contact with his young slave Sally, while at the same time putting her in a position to claim her freedom. With no wife to take care of his servants' well-being while he was minister to France, Jefferson was put in the position of buying Sally's clothes and seeing to her inoculation against smallpox, roles which Gordon-Reed speculates raised the level of intimacy between them (Hemingses, 299). She argues that for many reasons "the quality and substance of their conversations had to have been different" than it would have been in Virginia (Hemingses, 270). Jefferson read French but spoke it poorly so he may have been drawn to those in his household, like Sally Hemings and her brother James, with whom he could speak English, especially since Sally brought news from home. Hemings was legally free in France and for the first time in her life, she earned wages for her work, which may have made her see herself differently. Many years later her son Madison recounted in his reminiscences that Thomas Jefferson had to bargain with his slave Sally Hemings to get her to return to Virginia. Historian Philip Morgan notes her "influence over Jefferson" as well, giving as evidence that she gained "the freedom of all her children, the only case of an entire enslaved Monticello family achieving freedom" (77).

The novelist and screenwriters who represent the beginning of their relationship in Paris often turn to the senses and to the cultural context of eighteenth-century Virginia, just as the historian Gordon-Reed does, to imagine the motivations behind Jefferson's and Hemings's seemingly paradoxical behaviors. Although no likeness of Sally Hemings survives, we know that she was Jefferson's deceased wife's half-sister, that she had only one-quarter African ancestry, that she was described as beautiful by both blacks and whites, and that in 1830 she was listed in the U.S. Census as white. Jefferson's former slave Isaac Jefferson described her as "mighty near white" with "straight hair down her back." Chase-Riboud's novel depends on the visual (Hemings's "pale complexion," and her resemblance to Jefferson's deceased wife) and the auditory (her "soft Virginia accent," described as "a relief to his ears from the harsh beauty of the French") to make the fictional case for Jefferson's attraction to Sally Hemings (90-91), while the more visual and auditory medium of film exaggerates Hemings's African features and renders her speech as different in order to mark her slave status for viewers.

7 What the novel Sally Hemings allows for that the films, Jefferson in Paris and Sally Hemings, do not, at least as they are cast and directed, is for the reader to imagine the quite likely possibility that Sally Hemings physically resembled Thomas Jefferson's wife, her half sister. Martha Jefferson's father, John Wayles, had six children with his mulatto slave Elizabeth Hemings when he was a widower. In the novel, such a statement of resemblance does not depend on casting and so ironically the 
predominately white racial ancestry of Sally Hemings can be more realistically evoked by the written word. In the made-for-television movie, Sally Hemings: An American Scandal, Sam Neil, who plays Thomas Jefferson, is mesmerized when he first sees Sally Hemings, asking his slave/servant James, Sally's brother, who she is. This scene perfectly captures the uncanny feeling Jefferson may have experienced on seeing Sally Hemings in Paris. Actor Sam Neil is depicted as initially glimpsing her reflection in a mirror, almost as if his wife were brought back from another world. Later when he verbalizes his thoughts to Sally ("You look exactly like my wife. The resemblance is uncanny"), I suspect that most viewers are struck, not by the possibility of physical similarity but by racial difference, given the actress Carmen Ejogo's African features and skin tone. Ejogo's mother is Scottish and her father Nigerian. Although she is breathtakingly beautiful, all I could think when I heard these lines was that she did not resemble Martha Jefferson. Indeed my students, both black and white, laughed at this line when they saw the movie. Unlike fiction, film fixes the visual image, offering what literary critic Fredric Jameson calls "a translation" and therefore paradoxically something "closer to language" than reality in presenting a "materialized subjectivity" (3).

8 Leni Sorenson, a researcher at Monticello and historical consultant for Sally Hemings: An American Scandal, could not picture Ejogo as resembling Martha Jefferson either. Sorenson, who is herself biracial, thought Ejogo, despite her beauty, was miscast. As historical consultant, Sorenson raised this concern before filming began but to no avail. Screenwriter Tina Andrews and director Charles Haid had involved Sorenson in the making of the mini-series only after the casting was complete, as if the historical facts of Sally Hemings's racial ancestry were not important. Sorenson was similarly dismayed about the casting of Thandie Newton in Jefferson in Paris, although she was not the historical consultant for that film. Like Ejogo, Newton is biracial; her mother is British and her father Zimbabwean. Sorenson worries that such casting does not reflect the "nuances" of the historical truth of Sally Hemings's racial and familial ancestry and so perpetuates the myth than one "can always tell if someone has African ancestry"-a myth first born of white fear of impurity and later sometimes spread out of African American desire for racial solidarity.

Unlike Chase-Riboud, who renders Sally Hemings' speech like that of the white characters in her novel, in the film Jefferson in Paris Ruth Prawer Jhabvala creates a slave dialect for Hemings. She and her fellow British filmmakers drew a bright line between their well-spoken Jefferson and his slave, using Sally's highly inflected speech, ungrammatical and singsong, to remind both Jefferson and their audience of plantation life at Monticello. In making this choice, their Sally Hemings entertains Jefferson and thus becomes, as more than one reviewer noted, the stereotypical "pickaninny" (Zibart) distracting the master with song and dance. Interestingly, historian GordonReed believes that speech patterns may have been one more way that Sally Hemings actually reminded Jefferson of Martha. Besides resembling each other physically, halfsisters can resemble each other "in the tone and timbre of voice, and mannerisms." Furthermore, Gordon-Reed points out that "even before they were together in Paris, the Hemingses and Jeffersons lived in close proximity to one another and interacted on a daily basis, creating as this did all over the South, a mixed culture of shared language, expressions, sayings, and norms of presentation." She argues that Hemings's "manner of speaking was probably not markedly different from either of theirs," offering as evidence Henry Lee's comments that Jefferson's diction was "far from perfect" and 
Patsy Jefferson's "phonetic spelling of 'windows' as 'winders" in a letter describing the beautiful stained-glass "winders" she had seen in French cathedrals (Hemingses, 284).

British filmmakers' decision to render Sally Hemings's speech as so different from Jefferson's in Jefferson in Paris may stem from a desire to find as many ways as possible to remind viewers of Hemings's slave status and surely originates in stereotypical notions about the differences between white masters and black slaves, fostered no doubt by American local colorists' early renderings. Gordon-Reed believes such representations "grew out of a desire to cast African Americans as alien beings, in much the same way that Jim Crow was designed to communicate the message of essential differences between the races" (Hemingses, 285). A decade after Jefferson in Paris was released, historian Melvin Patrick Ely's recent research reveals how much alike the idioms and speech patterns of slaves and masters actually were through his analysis of the letters and other documents written by white and black residents of Prince Edward County, Virginia, during the late eighteenth and nineteenth centuries (290-95).

11 Despite filmmakers' reliance on their audience's senses of sight and hearing to reveal identity, racial ancestry is not always audible or visible. Chase-Riboud makes this doubly plain by opening her novel with the perspective of Nathan Langdon, the 1830 white census taker, who is "unnerved" by Sally Hemings's physical beauty and startled to discover that she is "fair enough to be his [own] mother" (8). Nathan becomes the first in a series of characters-historical and fictional-that Chase-Riboud employs to emphasize not just Sally Hemings's physical appearance but her alluring presence. Chase-Riboud's purpose is not so much to "insinuate into the consciousness of white readers the humanity of a people they otherwise constructed as subhuman" (8), which as Ann DuCille argues was the strategy of earlier African American writers who employed the mulatta figure, but to conjure a very specific individual, Sally Hemings, whom white male historians had reduced to an abstraction. By using Nathan as a doppelgänger for Thomas Jefferson, Chase-Riboud doubles her chances of convincing white readers why Jefferson would have chosen as his life partner Sally Hemings when as Nathan points out, "he could have chosen any white woman alive" (8). Not only does Chase-Riboud depict Sally as "the most beautiful woman" Nathan had ever seen (8), but she depicts Nathan as "charmed" by her "art of conversation" (13) and captivated by the sound of her voice, which "floated like silk scarves, sweeping and billowing the simple everyday language into a honeyed intimacy" (12).

12 Nathan, who is half Sally's age, literally becomes addicted to her presence, returning day after day until he convinces himself he has fabricated her race on the census form, not to protect Jefferson from miscegenation, his original reason, but to protect Hemings, a freed slave, from having to leave Virginia and proximity to him. This behavior provides another possible similarity to Jefferson who freed his children with Sally, but not Sally herself, leaving that task to his white daughter Martha (Patsy). Virginia law required freed slaves to leave the state unless special permission was granted by the state legislature. In the novel, after Sally spurns Nathan when she discovers that he has falsified her race, he becomes obsessed with her and her relationship with Jefferson, interviewing all who might have met her. Thus he becomes the first in a long line of historians, amateur and professional, many at first determined to suppress her story, others more recently to penetrate the mystery of her allure. Chase-Riboud constructs this subplot so that meeting Sally Hemings changes Nathan's 
life, just as it altered Jefferson's. Throughout the novel, Chase-Riboud repeatedly has historical characters from John Adams to Jefferson's daughter Patsy note Sally's resemblance to Martha Jefferson, no doubt as preparation for her representation of Jefferson and Hemings's first sexual encounter, a scene in which Jefferson unconsciously calls Sally "Martha."

In the novel, their relationship is set up as fated on both sides. Because Sally's mother, grandmother, and sisters have all had liaisons with white men, Chase-Riboud represents Sally as having the power to "hasten or delay" the start of their sexual relationship, but "powerless" to stop it (103). During Jefferson's travels in Dusseldorf after Sally Hemings's arrival in Paris, he saw Van der Werff's painting of the Biblical story of Sarah giving the slave Hagar to Abraham and in a letter to Maria Cosway he recounted how moved he was by the tableau. Chase-Riboud imagines that after Dusseldorf, Jefferson thought of Sally "often with a growing sense of fatality" (117). In a flashback Chase-Riboud positions Sally in the room of the dying Martha Jefferson, who allegedly made her husband promise not to remarry, thereby placing Jefferson in the position of taking a mistress in order to honor his wife's dying wish that her daughters not have a stepmother.

Chase-Riboud's representation of the beginning of their relationship, like the screenplays of Jhabvala and Andrews, breaks the link with a master-slave narrative of forcible sex, even as it reminds readers of Sally Hemings's slave status. The novel complicates the one-dimensional racial concerns by raising matters of social class. A French character who does not know that Sally is African American, although she does know she is a servant, admires her grace, expecting "her manners and gentleness and soft, charmingly accented French" to convey a "breeding" that will "surely attract a gentleman of property and improve her station in life" (112). By the time Jefferson leaves Paris for Monticello in 1789, two years after Sally's arrival, Chase-Riboud, like screenwriter Tina Andrews, represents Sally Hemings as a French lady with a southern accent, who reminds Jefferson of both the beautiful "rare objects" (130) that he purchased in Paris and the "sweet breath" (89) that draws him to Monticello:

A small, exquisite, heavy-breasted, slim-waisted body had emerged from the coltish and countrified adolescent of a year ago. She had honed her natural grace and inborn elegance on the examples of the most fashionable ladies of Pathemont and Paris on whom she spied incessantly and indecently, and had developed a lust for clothes and a taste for finery that went with such examples. She had lessons in French, in music, dressmaking. In her seclusion, Sally was better read than most ladies (130).

Whether she lived at Jefferson's residence, the Hôtel de Langeac on the ChampsElysées, as the novel and films suggest, or at his daughters' boarding school, Abbaye de Panthemont, is unknown. In Madison Hemings's remembrance of his mother, he remarked how often she spoke of life in France, proof perhaps that Sally Hemings was changed by her sojourn there.

To one degree or another, in the filmic and fictional renderings of their liaison and in Gordon-Reed's history, Jefferson, like Pygmalion, creates Hemings into his ideal life partner. Near the end of his stay in France, Jefferson wrote to an American female friend contrasting American angels with European Amazons:

an angel let the man in her life take the lead and make the important decisions affecting their lives. She accepted his well-tempered dominance and a show of his love and desire to protect her and their family. The dreaded Amazons, on the other 
hand were politically and socially assertive women who sought self-fulfillment outside of the home, challenging men in what was supposed to be an exclusively male domain.

Thus Gordon-Reed speculates that when Thomas Jefferson left Paris, Sally Hemings, not Maria Cosway, "represented the place and way of life he expected to return to [...] a shared universe in which he would be the unquestioned center." In Jefferson in Paris, a crucial scene binding Jefferson to Hemings and creating a distance between Jefferson and Cosway is set in the Virginia garden Jefferson created at the Hôtel de Langeac. Dumas Malone speculated that the very existence of this garden betrays Jefferson's homesickness for Monticello. The film portrays Jefferson and Hemings's shared delight at roasting fresh corn in the garden as a past time that is much too rustic for Cosway's refined tastes and a shared provincial pleasure that gives her a different impression of both Jefferson and his relationship with Hemings.

Interestingly neither Chase-Riboud, Jhabvala, nor Andrews suggests that Sally's attraction to Thomas was physical, perhaps because of the thirty-year age difference, perhaps because prevailing narratives and contemporary racial ideologies have rendered this interpretation unimaginable. Instead Chase-Riboud imagines that as a teenager far from home Sally sees Thomas, a powerful man in his 40 s, as a protector. Jhabvala spotlights as attractive Jefferson's influential position, both at home and abroad. Tina Andrews portrays Sally as an eager pupil to Jefferson, a willing teacherknowledgeable in all subjects from language and ideas to manners and haute couture. Only historian Gordon-Reed posits that Sally may have been physically attracted to Jefferson given the physical features of her racially mixed family members and the fact that all of the Hemings women had long-term relationships with either high-status white males or white workers or racially mixed servants from other plantations. Thus just as the 1979 novel and the 2000 television movie exhibit the social and political concerns of their day, Gordon-Reed's 2008 version of the story reflects America's current fascination with the racially-mixed figure and a willingness to move beyond the racial dichotomies of the late twentieth century.

Despite the best intentions to recreate the Hemings-Jefferson affair so that viewers could imagine the unimaginable, some stereotypical notions about racial identity creep into the filmic representations of Hemings and writers of both the novel and the TV script cannot imagine the mature Hemings as other than a champion of black causes or a standard bearer for women's rights, unsurprising echoes of the social and political context in which they were written. Only Gordon Reed allows Sally Hemings to remain an angel in Jefferson's house. But like the writers of both the film, the TV movie, and the novel, Gordon Reed must depart from the usual reliance on historical facts about Sally Hemings to make her so. Since no letters or diaries have been found that reveal the nature of their relationship, Gordon-Reed relies on the social context and the documented history of Jefferson's contemporaries to paint her portrait: older men marrying much younger women (by today's standards underage teenage girls) and southern white widowers' long-term common-law marriages to black housekeepers. By accumulating this evidence, she makes the case for her readers that Jefferson's liaison with a much younger woman was not out of the ordinary, that a long-term relationship with a woman of color was within the norm of southern plantation society, and that his attraction was based on something more than sex. Gordon-Reed views Sally Hemings's return to Virginia as reasoned, not coerced, a way for a slave to become the mistress of Monticello and see her children freed. Gordon-Reed makes her case by stepping away 
from her historical "narrative" (her phrasing) to construct an argument for a loving relationship in four chapters (14-17) at the center of her Hemings family history. Her attempt may be closer to the dynamic of Hemings and Jefferson's relationship than that of the novelist and the screenwriters, but it is still an imagined life. While Chase-Riboud and Tina Andrews perhaps make the older Sally Hemings more sympathetic to black readers and audiences by representing an increasing emotional distance from Jefferson and a growing feeling of black solidarity (in the novel Hemings attends Nat Turner's trial; in the TV movie she aids runaway slaves), Gordon-Reed locates sympathy for Hemings in her role as slave mother of the master's child-in the bargain her son Madison said that she struck with Jefferson, to return to Monticello only if he freed the child conceived in Paris.

In Eric Foner's review of The Hemingses of Monticello, he points out that although "most scholars are likely to agree with Gordon-Reed's conclusion that Jefferson fathered Hemings's seven children (of whom three died in infancy)," he believes that her portrait of the "enduring romance" (his phrase, not hers) is questionable (17). But in attempting to diminish her representation of their relationship, he never even mentions some of her most compelling arguments, many having to do with the power of the senses, which may have led to their mutual attraction, and the power of traditional gender roles that may have sustained it. Has Gordon-Reed been too early influenced by her reading of Barbara Chase-Riboud's novel? Or has Eric Foner's thinking been indelibly marked by the very master narrative that Gordon-Reed seeks to unsettle? What is clear is that each generation of novelists, screenwriters, and historians, to one degree or another, continues to fashion the Jefferson-Hemings narrative in a way that reveals, not surprisingly, as much about the preoccupations of their own era as those of the eighteenth century. But what is remarkable about these four representations is that a novelist, two screenwriters, and a historian have finally unsettled the old oppressor-oppressed paradigm and in doing so revealed the humanity of Sally Hemings and the humanness of Thomas Jefferson.

\section{BIBLIOGRAPHIE}

ADAMS, Henry, History of the United States During the Administration of Thomas Jefferson and James Madison, 2 volumes, Earl N. Harbert, ed., New York, Library of America, 1986, Vol. I (Jefferson), 101.

BARTA, Tony, ed., Screening the Past: Film and the Representation of the Past, Westport, CT, Praeger Publishers, 1998.

BERLIN, Ira, Many Thousands Gone: The First Two Centuries of Slavery in America, Cambridge, Harvard University Press, 1998.

BEAR, James A., Jr. ed., Jefferson at Monticello, Charlottesville, University Press of Virginia, 1967.

BERARDINELLI, James, Review of Jefferson in Paris, 1995, http://www.reelviews.net/movies/j/ jefferson.html (last accessed on June 28, 2009). 
BRODIE, Fawn M, Thomas Jefferson: An Intimate History, New York, W. W. Norton \& Co. Inc., 1974. BURGOYNE, Robert, The Hollywood Historical Film, Hoboken, NJ, Wiley-Blackwell, 2008.

BURNSTEIN, Andrew, The Inner Jefferson: Portrait of a Grieving Optimist, Charlottesville, University Press of Virginia, 1996.

CHASE-RIBOUD, Barbara, Sally Hemings, New York, Viking Press, 1979.

DABNEY, Virginius, The Jefferson Scandals: A Rebuttal, New York, Dodd and Mead, 1981.

DAVIS, Natalie, Slaves on Screen: Film and Historical Vision, Cambridge, MA, Harvard University Press, 2002.

DECKER, William Merrill, "Americans in Europe: Henry James to the Present," The Cambridge Companion to American Travel Writing, Alfred Bendixen and Judith Hamera, eds., New York, Cambridge University Press, 2009, 127-44.

DORAN, Robert, ed., The Fiction of Narrative: Essays on History, Literature, and Theory, 1957-2007, Baltimore, The Johns Hopkins University Press, 2010.

DuCILLE, Ann, The Coupling Convention: Sex, Text and Tradition in Black Women's Fiction, New York, Oxford University Press, 1993.

EBERT, Roger, Review of Jefferson in Paris, 7 April 1995, http://rogerebert.suntimes.com (last accessed on June 28, 2009).

ELLISON, Ralph, William STYRON, Robert Penn WARREN, and C. Vann WOODWARD, “A Discussion: The Uses of History in Fiction," Southern Literary Journal 1.2, spring 1969.

ELY, Melvin Patrick, Israel on the Appomattox: A Southern Experiment in Black Freedom from the 1790s through the Civil War, New York, Knopf, 2004.

FOX-GENOVESE, Elizabeth, Within the Plantation Household: Black and White Women of the Old South, Chapel Hill, University of North Carolina Press, 1988.

FONER, Eric, “The Master and the Mistress," New York Times Book Review, 5 October 2008, 17.

GRAMSCI, Antoni, Selections from the Prison Notebooks, Quintin Hoare and Geoffrey Nowell Smith, eds. and trans., New York, International Publishers, 1978.

GOMEZ, Michael, Exchanging Our Country Marks: The Transformation of African Identities in the Colonial and Antebellum South, Chapel Hill, University of North Carolina Press, 1998.

GORDON-REED, Annette, The Hemingses of Monticello, New York, W.W. Norton and Company, 2008.

---, Thomas Jefferson and Sally Hemings: An American Controversy, Charlottesville, University of Virginia Press, 1997.

HODES, Martha, White Women, Black Men: Illicit Sex in the Nineteenth-Century South, New Haven, Yale University Press, 1997.

HEMINGS, Madison, "Reminiscences of Madison Hemings," [1873], Included as Appendix 1, Part 1 in Fawn M. Brodie's Thomas Jefferson: An Intimate History, New York, W. W. Norton \& Co. Inc., 1974.

HOOKS, bell, Yearning: Race, Gender, and Cultural Politics, Boston, South End Press, 1990.

JAMESON, Fredric, Signatures of the Visible, New York, Routledge, 1990.

Jefferson in Paris, Dir. By James Ivory, Touchstone Pictures, 1995.

JEFFERSON, Thomas, Notes on the State of Virginia, William Peden, ed., [1787], New York, W.W. Norton and Company, 1972. 
JONES, Suzanne, Race Mixing: Southern Fiction since the Sixties, Baltimore, Johns Hopkins University Press, 2004.

JORDON, Winthrop D, White over Black: American Attitudes toward the Negro, 1550-1812, Chapel Hill, University of North Carolina Press, 1968.

---, "Hemings and Jefferson: Redux," Sally Hemings \& Thomas Jefferson: History, Memory, and Civic Culture, Jan Ellen Lewis and Peter S. Onuf, eds., Charlottesville, University Press of Virginia, 1999.

KIERNER, Cynthia A, Scandal at Bizarre: Rumor and Reputation in Jefferson's America, New York, Palgrave Macmillan, 2004.

LANDY, Marcia, ed., The Historical Film: History and Memory in Media, New Brunswick, NJ, Rutgers University Press, 2000.

“L'histoire saisie par la fiction," Le Débat, 165.3, mai-juin 2011.

LEWIS, Jan Ellen, and Peter S. ONUF, eds., Sally Hemings \& Thomas Jefferson: History, Memory, and Civic Culture, Charlottesville, University Press of Virginia, 1999.

MALONE, Dumas, Jefferson and His Time, 6 vols, Boston, Little, Brown, 1948-81.

McCARTHY, Todd, Review of Jefferson in Paris, Variety, 27 March 1995, Web (last accessed on June $28,2009)$.

MILLER, John C., The Wolf by the Ears: Thomas Jefferson and Slavery, New York, Free Press, 1977.

MONTEITH, Sharon, “America's Domestic Aliens: African Americans and the Issue of Citizenship in the Jefferson/Hemings Story in Fiction and Film" in Alien Identities: Exploring Difference in Film and Fiction, Deborah Cartmell, I.Q. Hunter, Heidi Kaye, and Imelda Whelehan, eds., London, Pluto Press, 1999.

MORGAN, Philip D., "Interracial Sex in the Chesapeake and the British Atlantic World, c 1700-1820," in Sally Hemings \& Thomas Jefferson: History, Memory, and Civic Culture, Jan Ellen Lewis and Peter S. Onuf, eds., Charlottesville, University Press of Virginia, 1999.

---, Slave Counterpoint: Black Culture in the Eighteenth-Century Chesapeake and Lowcountry, Chapel Hill, University of North Carolina Press, 1998.

PARTON, James, The Life of Thomas Jefferson, Boston, Houghton, Osgood and Co., 1874.

PETERSON, Merrill, Thomas Jefferson and the New Nation, New York, Oxford University Press, 1970. PIERSON, Hamilton, Jefferson at Monticello: The Private Life of Thomas Jefferson, New York, Charles Scribner, 1862.

RANDALL, Henry S., The Life of Thomas Jefferson, 3 vols, New York, Derby and Jackson, 1858.

RANDALL, William Sterne, Thomas Jefferson: A Life, New York, H. Holt, 1993.

ROSENSTONE, Robert, ed., Revisioning History: Film and the Construction of a New Past, Princeton, NJ, Princeton University Press, 1995.

Sally Hemings: An American Scandal, Dir. by Charles Haid, CBS, 2000.

SORENSON, Leni, Telephone interview, Charlottesville, Virginia, 10 October 2008.

STANTON, Lucia, Slavery at Monticello, Charlottesville, Thomas Jefferson Memorial Foundation, 1996.

STEVENSON, Brenda E., Life in Black and White: Family and Community in the Slave South, New York, Oxford University Press, 1996. 
THORNTON, John, Africa and Africans in the Making of the Atlantic World, 1400-1800, Cambridge University Press, 1998.

WHITE, Deborah Gray, Ar'n't I a Woman?: Female Slaves in the Plantation South, New York, Norton, 1999.

ZIBART, Eve, Review of Jefferson in Paris, The Washington Post, 7 April 1995.

\section{AUTEUR}

SUZANNE W. JONES

University of Richmond 